\title{
Analisis Lokasi dan Pola Sebaran Pasar Modern di Kota Yogyakarta, Kabupaten Sleman dan Bantul
}

\author{
Tri Wahyuningsih \\ Universitas Indonesia \\ Sonny Harry B. Harmadi* \\ Universitas Indonesia
}

\begin{abstract}
The development of modern market which is penetrated into the rural areas has positive impacts on fast distribution of goods and price stability in that region. However, people are afraid that the change of city spatial functions will bring more harm to the existence of a traditional market or a small retailer that is the source of living for lower-middle income group. This study identifies some factors influencing the number of modern market in Yogyakarta city, Selman and Bantul regencies by considering the spatial interaction pattern among districts. The results show that the location of modern market is influenced by population density and quality of road infrastructure. There is a spatial dependence among the location of modern markets in a form of spatial error model. The identification of spatial error is believed that there are several variables which are not included in the model but has an important role spatially, namely the price of land and local government policy.
\end{abstract}

Keywords: pasar modern, ritel, dependensi spasial

\section{PENDAHULUAN}

Pusat perbelanjaan modern seperti department store, mall/plaza, hypermarket, supermarket, minimarket dan pusat perbelanjaan modern lainnya yang tumbuh dan berkembang saat ini telah menciptakan sistem one-stop shopping yang memberikan banyak kemudahan bagi konsumen.Selain sebagai tempat berbelanja, pusat perbelanjaan modern umumnya dilengkapi juga dengan fasilitas arena bermain anak-anak, bioskop, rumah makan hingga fasilitas olah raga.

Berbelanja di pusat perbelanjaan/pasar modern juga dianggap dapat meningkatkan status sosial seseorang disamping juga pertimbangan kebersihan, kenyamanan, kualitas produk yang lebih baik dan harga yang cukup bersaing. Faktor mobilitas dan waktu yang terbatas karena kesibukan pekerjaan menyebabkan seseorang lebih memilih

\footnotetext{
* Korespondensi: Sonny Harry B. Harmadi, Departemen Ilmu Ekonomi dan Lembaga Demografi, Fakultas Ekonomi dan Bisnis, Universitas Indonesia. Email: sonny_harmadi@yahoo.com
} 
berbelanja di pasar modern daripada pasar tradisional yang terkesan kotor dan kumuh. Selain itu, ketidakpastian harga dan terkadang kecurangan yang dilakukan oleh beberapa penjual terkadang membuat sebagian orang merasa enggan berbelanja di pasar tradisional.

Pada tahun 2008, dari sekitar 11.866 gerai pasar modern, sekitar $83 \%$ berlokasi di pulau Jawa. Provinsi DKI Jakarta, Jawa Barat dan Jawa Timur menjadi daerah dengan jumlah gerai pasar modern terbanyak. Terkonsentrasinya gerai-gerai pasar modern di pulau Jawa tidak lepas dari kondisi dimana konsentrasi penduduk dan pusat perekonomian Indonesia berada di pulau ini (Pandin, 2009).

Sektor ritel merupakan sektor kedua terbesar dalam hal penyerapan tenaga kerja. Data BPS per Agustus 2011 menunjukkan bahwa sektor ritel menyerap 23,4 juta tenaga kerja, atau nomor dua setelah sektor pertanian yang menampung 39,3 juta tenaga kerja usia di atas 15 tahun. Ritel menjadi industri jasa yang sangat penting dalam perekonomian karena kontribusinya yang sangat besar dalam pembentukan Gross Domestic Product (GDP). Industri jasa ini menempati posisi terbesar kedua setelah industri pengolahan. Kondisi inilah yang diyakini menjadi daya dorong pemulihan pertumbuhan ekonomi Indonesia pasca krisis tahun 1998 (KPPU, 2012).

Hampir di seluruh wilayah di Indonesia, pasar modern yang bergerak di bidang ritel, seperti hypermarket, supermarket dan minimarket telah merambah ke perkampungan dan desa. Fenomena tersebut juga terjadi di Yogyakarta, bercampurnya berbagai macam kultur budaya mengakibatkan perubahan gaya hidup masyarakat yang diindikasi dapat menjadi salah satu faktor penyebab berkembangnya sektor ritel di daerah ini.

Kota Yogyakarta terletak pada posisi yang sangat strategis yaitu sebagai pusat pemerintahan di provinsi Daerah Istimewa Yogyakarta dan berada ditengah-tengah 4 (empat) kabupaten tetangga yaitu Bantul, Sleman, Kulon Progo dan Gunung Kidul. Dalam penelitian ini, wilayah penelitian adalah kota Yogyakarta, kabupaten Sleman dan Bantul dengan pertimbangan bahwa kota Yogyakarta berbatasan langsung dengan dua kabupaten tersebut.

Gambar 1 menyajikan peta sebaran pasar modern di kota Yogyakarta, kabupaten Sleman dan Bantul yang menunjukkan adanya pola cluster (mengelompok) dan mengerucut ke arah kota Yogyakarta sebagai pusat kota dan pemerintahan. Kondisi inilah yang pada akhirnya menimbulkan kekhawatiran terjadinya perubahan fungsi keruangan kota dan juga kemacetan dari kegiatan retail pada lokasi-lokasi strategis serta dampak sosial dari kegiatan retail modern terhadap eksistensi dari pasar tradisional dan retailer kecil.

Berbagai penelitian tentang analisis lokasi pusat perbelanjaan dan ritel telah dilakukan untuk mengidentifikasi faktor-faktor yang mempengaruhi permintaan ritel. Hasil penelitian terdahulu pada dasarnya menunjukkan bahwa faktor demografi dan sosioekonomi memegang peranan penting. Beberapa faktor bisa mempunyai pengaruh 
yang signifikan di suatu daerah, namun belum tentu berpengaruh sama untuk daerah yang lain, karena kultur atau budaya setiap negara ataupun daerah yang belum tentu sama.

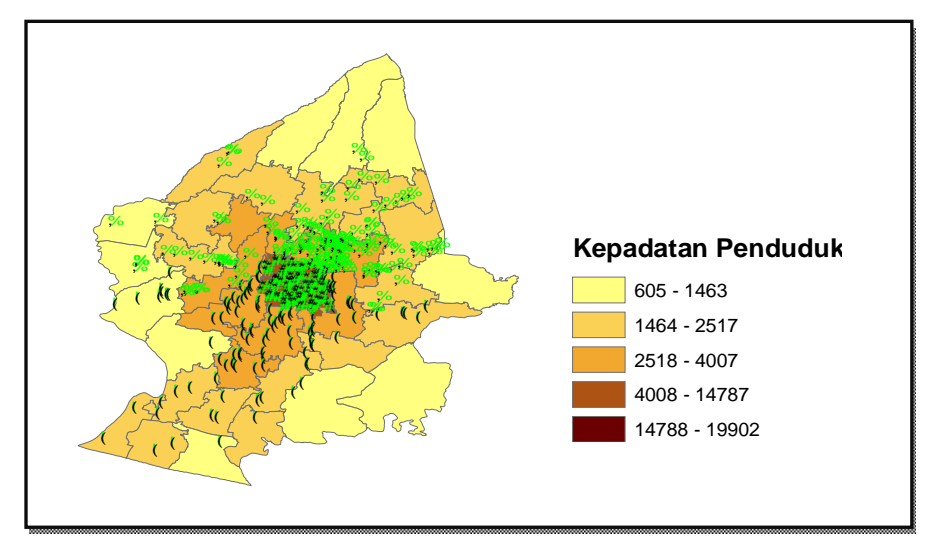

\section{Gambar 1. Peta Sebaran Pasar Modern dan Tingkat Kepadatan Penduduk Kota Yogyakarta, Kabupaten Sleman dan Bantul}

Informasi tentang karakteristik lokasi dapat ditangkap dengan menggunakan analisis data spasial, yaitu data yang memuat informasi lokasi yang seringkali memiliki pengaruh antara lokasi yang satu dengan lokasi lainnya. Dalam pemodelan data spasial, pengaruh ini dinamakan efek spasial. Setiap wilayah tidak dapat dipandang sebagai unit observasi yang berdiri sendiri dan tidak terkait dengan wilayah lainnya, sehingga diperlukan analisis spasial untuk mengkaji pengaruh hubungan antara lokasi yang satu dengan lokasi yang lainnya (Hadiarta, 2013).

Penelitian tentang keterkaitan spasial pusat perbelanjaan juga telah banyak dilakukan. Model yang digunakan dalam penelitian ini mengacu kepada penelitian Ozuduru (2013) yang menganalisis ketergantungan spasial pusat perbelanjaan di Ohio dengan menggabungkan model alokasi ritel berbasis gravitasi dan model spatial autoregressive (SAR). Hasil penelitian menunjukkan bahwa terjadi ketergantungan spasial antara pusat perbelanjaan dengan faktor permintaan ritel. Selain itu, informasi tingkat kepadatan ritel di tiap wilayah dapat digunakan untuk mengidentifikasi wilayahwilayah yang mengalami aglomerasi.

Bagaimana dengan kondisi pasar modern di kota Yogyakarta, kabupaten Sleman dan Bantul? Tujuan penelitian ini adalah untuk mengidentifikasi faktor-faktor yang mempengaruhi jumlah pasar modern yang ada di kota Yogyakarta, kabupaten Sleman dan Bantul dengan menggunakan hubungan antara supply dan demand pasar modern dengan mempertimbangkan adanya interaksi antar kecamatan melalui pendekatan spasial. 


\section{TINJAUAN PUSTAKA}

\subsection{Teori Lokasi dan Analisis Market Area}

Lokasi pusat perbelanjaan merupakan bagian penting dari strategi bisnis ritel yang berkaitan dengan jaringan ritel, transportasi, perumahan dan lingkungan serta karakteristik pasar dan lokasi pusat perbelanjaan lainnya dalam suatu daerah perdagangan (trade area atau market area).Trade area memiliki ketergantungan spasial, dimana seorang pelanggan yang berada di satu lokasi mungkin berbelanja di lokasi yang lain. Hal ini menunjukkan bahwa penjualan dari pusat perbelanjaan di satu lokasi dapat dipengaruhi oleh karakteristik pelanggan di daerah yang lain. Jika trade area suatu wilayah berada dalam kondisi undersupplied, konsumen yang bertempat tinggal di wilayah tersebut memiliki kecenderungan berbelanja di pusat perbelanjaan di lokasi lain. Hal ini menunjukkan bahwa terdapat potensi ruang ritel yang lebih banyak pada wilayah tersebut, sehingga membuka peluang untuk pembangunan fasilitas ritel baru. Sebaliknya, jika trade area suatu wilayah berada dalam kondisi oversupplied dapat menyebabkan beberapa usaha ritel gulung tikar karena mereka tidak mampu bersaing (Ozuduru, 2013).

Teori market area merupakan salah satu kelompok utama teori lokasi dalam analisa ekonomi regional. Teori ini, dipelopori oleh August Losch, menitikberatkan dari sisi permintaan (pasar). Losch (1954) mengatakan bahwa lokasi penjual sangat berpengaruh terhadap jumlah konsumen yang dapat digarapnya.Makin jauh dari tempat penjual, konsumen makin enggan membeli karena biaya transportasi semakin mahal, sehingga Losch menyarankan agar lokasi produksi berada di pasar atau di dekat pasar.

Ukuran market area ditentukan oleh beberapa faktor, antara lain: biaya transportasi, permintaan per kapita, kepadatan penduduk, skala ekonomi dan pendapatan (Sullivan, 1996).

1. Market area dan skala ekonomi

Peningkatan skala ekonomi akan meningkatkan market area sebuah toko. Dengan asumsi permintaan per kapita tetap, penambahan skala ekonomi akanmenambah output per toko sehingga setiap toko juga membutuhkan market area yang lebih luas.

2. Market area dan biaya transportasi

Penurunan biaya transportasi akan menyebabkan peningkatan market area karena setiap toko membutuhkan wilayah yang lebih luas untuk penjualan produk/outputnya, dengan asumsi permintaan per kapita tetap.

3. Market area dan permintaan per kapita

Permintaan produk/output akan meningkat seiring meningkatnya permintaan per kapita. Jika output per toko tetap sementara permintaan per kapita bertambah, maka setiap toko memiliki market area yang lebih kecil, sehingga akan berakibat pada bertambahnya jumlah toko. Sebaliknya, market area akan bertambah luas jika 
permintaan per kapita mengalami penurunan.

4. Market area dan kepadatan penduduk

Seperti halnya permintaan per kapita, permintaan produk/outputakan meningkat seiring meningkatnya kepadatan penduduk. Jika output per toko tetap sementara kepadatan penduduk bertambah, maka setiap toko memiliki market area yang lebih kecil, sehingga akan berakibat pada bertambahnya jumlah toko. Sebaliknya, jika terjadi penurunan kepadatan penduduk, maka market areaakan bertambah besar/luas.

5. Market area dan pendapatan

Hubungan antara pendapatan dan market area bersifat ambigu karena pendapatan dapat menimbulkan akibat baik pada permintaan per kapita maupun kepadatan penduduk.

Penelitian empiris pertama tentang teori area pasar dilakukan oleh Reilly (1929). Hasil penelitian ini dikenal dengan hukum Reilly yang berbunyi: "lokasi perusahaan industri cenderung terkonsentrasi pada beberapa pusat sedangkan jumlah industri yang masuk ke konsentrasi tersebut sebanding dengan luas daerah pasar (diukur dengan jumlah penduduk) dan berhubungan terbalik dengan jarak antara pusat dengan daerah pinggiran daerah pasar". Peta sebaran pasar modern di kota Yogyakarta, kabupaten Sleman dan Bantul dalam gambar 1 memperlihatkan bahwa semakin jauh dari pusat kota, pasar modern yang ada semakin sedikit. Disamping itu terlihat bahwa wilayah dengan tingkat kepadatan penduduk yang tinggi mempunyai jumlah pasar modern yang lebih banyak.

\section{METODE PENELITIAN}

\subsection{Jenis dan Sumber Data}

Jenis data yang digunakan dalam penelitian ini adalah data sekunder dalam bentuk lintas wilayah (cross section). Data penelitian adalah data pada tahun 2011 yang meliputi data toko modern, tingkat kepadatan penduduk, panjang jalan yang diaspal, penduduk berusia 15 tahun keatas, penduduk yang berpendidikan minimal SMA, jumlah kepala keluarga/rumah tangga miskin dan data pasar tradisional yang dikelola pemerintah daerah. Sedangkan informasi yang berkaitan dengan perbatasan dengan wilayah tetangga didapatkan melalui fasilitas Geographical Information System (GIS).

Data yang dikumpulkan didapatkan dengan menelaah berbagai publikasi/laporan di media cetak ataupun website yang ada pada institusi dan instansi pemerintah. Sedangkan untuk melihat dan menjelaskan pola sebaran pasar modern jika dikaitkan dengan variabel penelitian diperlukan data posisi geografis gerai/toko/pasar modern yang didapatkan penulis melalui bantuan Googlemaps. Data yang diperoleh memang tidak seakurat jika dilakukan survey langsung di lapangan, namun referensi dan 
pengujian sampel menunjukkan ketidakakuratan hanya berkisar 100 hingga 400 meter dari posisi sebenarnya.

\subsection{Metode Analisis}

\subsubsection{Analisis Spasial}

Hukum pertama tentang geografi dikemukakan oleh Tobler, menyatakan bahwa segala sesuatu saling berhubungan satu dengan yang lainnya, tetapi sesuatu yang dekat lebih mempunyai pengaruh daripada sesuatu yang jauh (Anselin, 1988). Hukum tersebut merupakan dasar pengkajian permasalahan berdasarkan efek lokasi atau metode spasial. Pendekatan spasial yang dilakukan pada penelitian ini adalah dengan menggunakan teknik analisis spasial ekonometri dan Geographical Information System (GIS).

Menurut Anselin (1999) dalam Hadiarta (2013), spasial ekonometri digunakan untuk menganalisis efek spasial yang merupakan fenomena yang lazim terjadi pada data cross section, dimana penggunaan metode ekonometri yang lain seringkali gagal untuk menggambarkan hal tersebut. Analisis spasial ekonometri digunakan untuk menguji seberapa besar interaksi atau hubungan antara variabel-variabel independen maupun dependen di suatu lokasi terhadap variabel dependen di lokasi lain.

\subsubsection{Model Regresi Klasik}

Model regresi linier adalah salah satu metode statistika yang membentuk sebuah model hubungan antara variabel respon $(Y)$ dengan satu atau lebih variabel prediktor $(X)$. Secara umum dapat dimodelkan seperti berikut :

$$
y_{i}=X_{i} \beta+\varepsilon_{i}
$$

Metode penaksiran parameter model pada persamaan (1) adalah dengan metode Ordinary Least Square (OLS). Pada model regresi klasik, variabel dependen $y_{i}$ tidak diasumsikan memiliki keterkaitan secara spasial terhadap variabel dependen yang lain $\left(y_{j, i \neq j}\right)$.

\subsubsection{Model Regresi Spasial}

Model umum regresi spasial (LeSage, 1999 dan Anselin, 1988) :

$$
\begin{array}{r}
y=\rho W_{1} y+X \beta+u \ldots . \\
u=\lambda W_{2} u+\varepsilon \ldots \ldots \ldots \ldots \\
\varepsilon \sim N\left(0, \sigma^{2} I\right)
\end{array}
$$

dimana :

$y \quad: \quad$ vektor variabel dependen

$X \quad$ : matriks variabel independen

$\beta \quad$ : vektor parameter koefisien regresi

$\rho \quad$ : parameter koefisien spatial lag variabel dependen

$\lambda \quad$ : parameter koefisien spatial lag pada error 


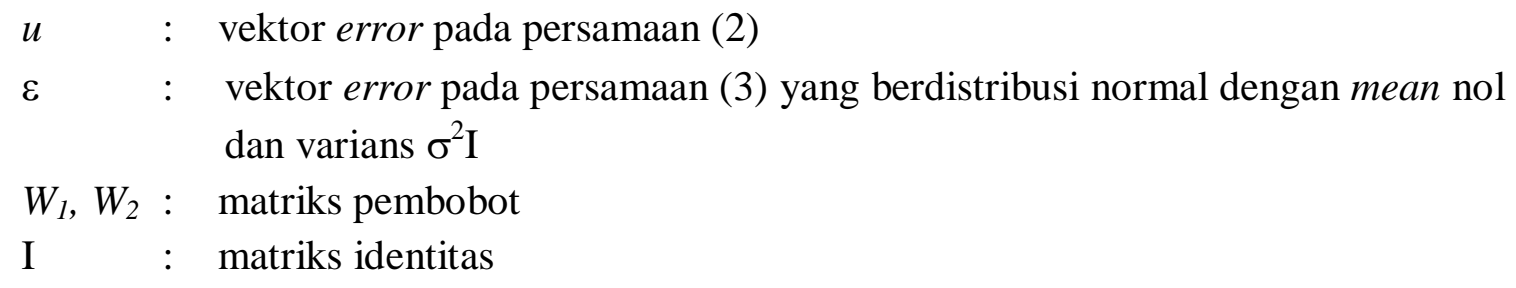

Error regresi $(u)$ diasumsikan memiliki efek lokasi random dan autokorelasi secara spasial. $W_{1}$ dan $W_{2}$ merupakan pembobot yang menunjukkan hubungan contiguity atau fungsi jarak antar lokasi dan diagonalnya bernilai nol. Anselin (1988) mengembangkan model regresi spasial dalam pemodelan data yang memuat spasial dependensi, yaitu spatial lag model dan spatial error model.Spatial lag model menangkap spasial dependensi yang teramati dalam variabel dependennya, sedangkan spatial error model menangkap spasial dependensi yang teramati dalam bagian errornya.

Model regresi spasial dalam penelitian ini menggunakan atribut jumlah gerai/toko/pasar modern di masing-masing wilayah yang menunjukkan tingkat retail supply dan karakteristik demografi dan wilayah yang menunjukkan retail demand seperti variabel kepadatan penduduk, panjang jalan yang diaspal, rasio penduduk berusia 15 tahun keatas, rasio penduduk yang berpendidikan minimal SMA, rasio jumlah kepala keluarga/rumah tangga miskin dan jumlah pasar tradisional yang dikelola pemerintah daerah serta informasi perbatasan dengan wilayah tetangga.Model regresi spasial yang digunakan dalam penelitian ini sebagai berikut :

$$
\begin{aligned}
& \operatorname{Ln}\left(Y_{i}\right)=\beta_{0}+\beta_{1} \operatorname{Ln}\left(X_{1 i}\right)+\beta_{2} \operatorname{Ln}\left(X_{2 i}\right)+\beta_{3} \operatorname{Ln}\left(\operatorname{sh} X_{3 i}\right)+\beta_{4} \operatorname{Ln}\left(\operatorname{sh} X_{4 i}\right)+\beta_{5} \operatorname{Ln}\left(\operatorname{sh} X_{5 i}\right)+ \\
& \beta_{6} \operatorname{Ln}\left(X_{6 i}\right)+\beta_{7} X_{7 i}+\beta_{8} X_{8 i}+\beta_{9} X_{9 i}+u_{i} \\
& u_{i}=\lambda \sum_{j=1, i \neq j}^{n} W_{i j} u_{j}+\varepsilon_{i}
\end{aligned}
$$

Dari persamaan (4) dan (5) dapat pula dituliskan model regresi spasial penelitian :

$$
\begin{aligned}
& \operatorname{Ln}\left(Y_{i}\right)=\beta_{0}+\lambda \sum_{j=1, i \neq j}^{n} W_{i j} u_{j}+\beta_{1} \operatorname{Ln}\left(X_{1 i}\right)+\beta_{2} \operatorname{Ln}\left(X_{2 i}\right)+\beta_{3} \operatorname{Ln}\left(\operatorname{sh} X_{3 i}\right)+\beta_{4} \operatorname{Ln}\left(\operatorname{sh} X_{4 i}\right)+ \\
& \beta_{5} \operatorname{Ln}\left(\operatorname{sh} X_{5 i}\right)+\beta_{6} \operatorname{Ln}\left(X_{6 i}\right)+\beta_{7} X_{7 i}+\beta_{8} X_{8 i}+\beta_{9} X_{9 i}+\varepsilon_{i}
\end{aligned}
$$

di mana,

$Y_{i} \quad: \quad$ jumlah gerai/toko/pasar modern di kecamatan i

$X_{1 i} \quad:$ tingkat kepadatan penduduk di kecamatan i

$X_{2 i} \quad$ : panjang jalan yang diaspal di kecamatan i

$\operatorname{sh} X_{3 i}$ : rasio penduduk berusia 15 tahun keatas di kecamatan i

$s h X_{4 i} \quad$ : rasio penduduk berpendidikan minimal SMA di kecamatan i

$s h X_{5 i} \quad$ : rasio jumlah kepala keluarga miskin di kecamatan i

$X_{6 i} \quad$ : jumlah pasar tradisional yang dikelola pemerintah daerah di kecamatan i

$X_{7 i} \quad$ : variabel dummy perbatasan dengan kota Yogyakarta

$X_{8 i} \quad$ : variabel dummy perbatasan dengan kabupaten Sleman

$X_{9 i} \quad$ : variabel dummy perbatasan dengan kabupaten Bantul 


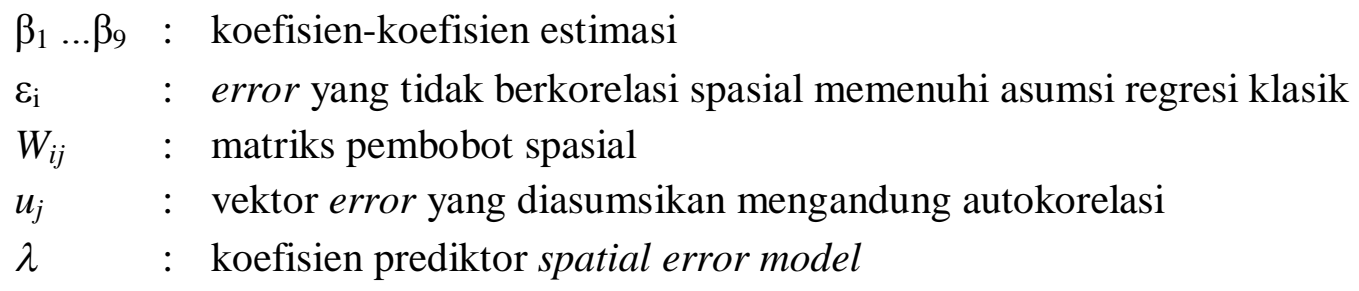

Tabel 1. Definisi dan penjelasan variabel-variabel

\begin{tabular}{|c|c|c|c|}
\hline No. & Variabel & Definisi & Satuan \\
\hline 1 & Jumlah Toko & Jumlah/banyaknya gerai/toko/pasar modern & unit \\
\hline 2 & Kepadatan penduduk & Menyatakan tingkat kepadatan penduduk & Jiwa/km \\
\hline 3 & Panjang jalan yang diaspal & $\begin{array}{l}\text { Menyatakan panjang infrastruktur jalan yang telah } \\
\text { diaspal }\end{array}$ & $\mathrm{Km}$ \\
\hline 4 & $\begin{array}{l}\text { Rasio penduduk berusia } 15 \\
\text { tahun keatas }\end{array}$ & $\begin{array}{l}\text { Menyatakan rasio/share jumlah penduduk berusia } \\
15 \text { tahun keatas, yang diperoleh dari jumlah } \\
\text { penduduk berusia } 15 \text { tahun keatas dibagi total } \\
\text { jumlah penduduk }\end{array}$ & Jiwa \\
\hline 5 & $\begin{array}{l}\text { Rasiopenduduk dengan } \\
\text { tingkat pendidikan minimal } \\
\text { SMA }\end{array}$ & $\begin{array}{l}\text { Menyatakan rasio/share jumlah penduduk } \\
\text { berpendidikan minimal SMA, yang diperoleh dari } \\
\text { jumlah penduduk berpendidikan minimal SMA } \\
\text { dibagi total jumlah penduduk }\end{array}$ & Jiwa \\
\hline 6 & $\begin{array}{l}\text { Rasio jumlah kepala } \\
\text { keluarga/rumah tangga } \\
\text { miskin }\end{array}$ & $\begin{array}{l}\text { Menyatakan rasio/share jumlah kepala } \\
\text { keluarga/rumah tangga miskin, diperoleh dari } \\
\text { jumlah kepala keluarga miskin dibagi total jumlah } \\
\text { kepala keluarga miskin. }\end{array}$ & KK \\
\hline 7 & Jumlah pasar tradisional & $\begin{array}{l}\text { Menyatakan banyaknya pasar tradisional yang } \\
\text { dikelola oleh pemerintah daerah }\end{array}$ & Unit \\
\hline 8 & $\begin{array}{l}\text { Perbatasan dengan wilayah } \\
\text { tetangga/ pusat kota } \\
(\text { dummy) }\end{array}$ & $\begin{array}{l}\text { Posisi dimana toko modern berbatasan (Kota } \\
\text { Yogyakarta, Kabupaten Sleman atau Bantul) }\end{array}$ & \\
\hline
\end{tabular}

\subsubsection{Spatial Lag Model (SLM)}

Pada persamaan (2), jika nilai $\mathrm{W}_{2}=0$ atau $\lambda=0$ dan $\rho \neq 0$, maka model akan menjadi model spatial lag :

$$
\begin{array}{r}
y=\rho W_{1} y+X \beta+\varepsilon \\
\varepsilon \sim N\left(0, \sigma^{2} I\right)
\end{array}
$$

Model spatial lag (SLM) atau spatial autoregressive model (SAR) adalah model spasial dengan pendekatan area yang memperhitungkan pengaruh spatial lag pada peubah dependen saja (Anselin, 1988). Variabel dependen berkorelasi spasial antara variabel dependen di suatu lokasi dengan variabel dependen di lokasi lain.

\subsubsection{Spatial Error Model (SEM)}

Pada persamaan (2), jika nilai $\mathrm{W}_{1}=0$ atau $\rho=0$ dan $\lambda \neq 0$, maka model akan menjadi model spatial error:

$y=X \beta+u$.

$u=\lambda W_{2} u+\varepsilon$ 
Atau dapat dituliskan dalam persamaan (9) menjadi :

$$
\begin{array}{r}
y=X \beta+\lambda W_{2} u+\varepsilon \\
\varepsilon \sim N\left(0, \sigma^{2} I\right)
\end{array}
$$

Spatial error model (SEM) adalah model regresi spasial dimana ketergantungan spasial masuk melalui error. Model spatial error mengasumsikan bahwa error dari sebuah model berkorelasi spasial dengan error pada lokasi lain (Panjaitan, 2012).

\subsubsection{Matriks Pembobot Spasial}

Matriks pembobot spasial merupakan matriks ketergantungan spasial (contiguity) yang menggambarkan hubungan antar daerah yang diperoleh berdasarkan informasi jarak atau ketetanggaan. Pembentukan matriks keterkaitan spasial (matrik $W$ ) dapat menggunakan berbagai teknik pembobotan. Menurut Anselin (1999) dalam Hadiarta (2013) ada beberapa cara dalam mengidentifikasi bobot tersebut, diantaranya:

a. Contiguity (common boundary), misalnya batas fisik administratif wilayah. Wilayah yang didefinisikan sebagai tetangga adalah wilayah yang secara fisik berbatasan langsung terhadap batas administratif wilayah lain. Secara umum terdapat berbagai tipe interaksi, yaitu Rook contiguity, Bishop contiguitydan Queen contiguity.

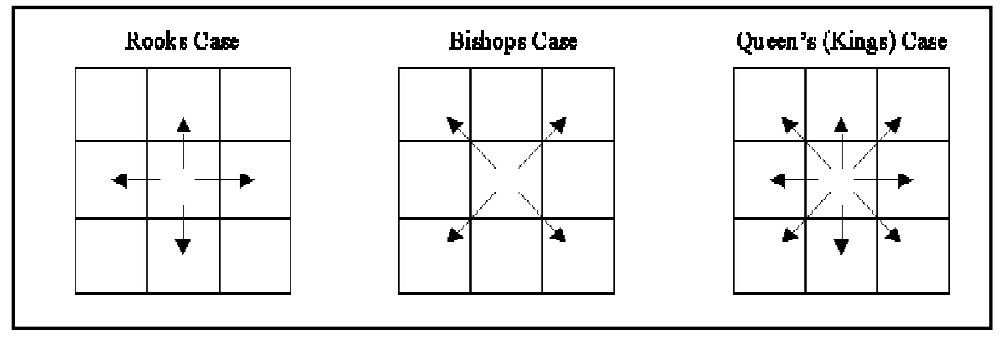

Gambar 2. Matriks Pembobot Spasial Contiguity

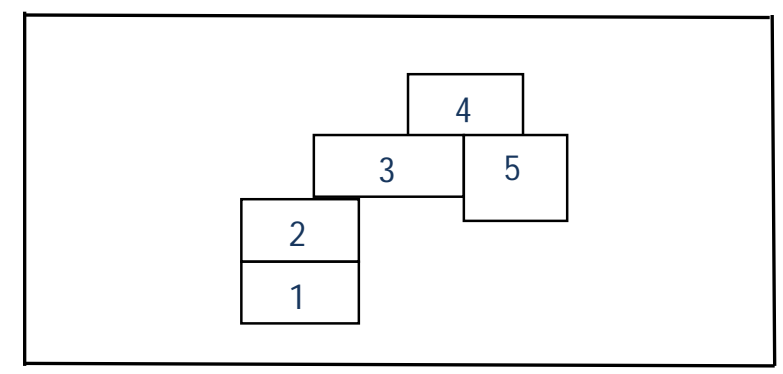

\section{Gambar 3. Ilustrasi Matriks Pembobot Spasial}

i. Benteng Catur (Rook Contiguity), ialah persinggungan sisi (common side) wilayah satu dengan sisi wilayah yang lain yang bertetanggaan. Pada gambar 3, wilayah 1 bersentuhan dengan wilayah 2 sehingga $W_{12}=1$ dan yang lain 0 atau pada wilayah 3 bersentuhan dengan wilayah 4 dan 5 sehingga $W_{34}=1, W_{35}=1$ dan yang lain 0 
ii. Gajah Catur (Bishop Contiguity), ialah persinggungan sudut (common vertex) wilayah satu dengan wilayah tetangga yang lain. Pada gambar 3, wilayah 2 bersentuhan titik dengan wilayah 3 sehingga $\mathrm{W}_{23}=1$ dan yang lain 0 .

iii. Ratu Catur (Queen Contiguity), ialah persentuhan baik sisi maupun titik vertek wilayah satu dengan wilayah yang lain yaitu gabungan rook contiguity dan bishop contiguity. Dari gambar $3, \mathrm{~W}_{32}=1, \mathrm{~W}_{34}=1, \mathrm{~W}_{35}=1$ dan yang lain 0 .

b. Distance (distance band dan k-nearest neighbors), misalnya jarak antar wilayah. Semakin jauh jarak akan semakin lemah hubungan ketetanggaan, sehingga semakin kecil juga pengaruhnya.

c. General (socio-economic distance), misalnyaintensitas interaksi individu wilayah lain yang didekati oleh jumlah migrasi penduduk. Wilayah lain yang disebut tetangga adalah wilayah yang terdapat migrasi penduduk dalam intensitas tertentu terhadap wilayah lain. Semakin banyak penduduk yang melakukan perpindahan antar wilayah lain, akan semakin kuat hubungan ketetanggaannya, sehingga semakin besar juga pengaruhnya.

\subsubsection{Pengujian Efek Spasial}

Pengujian efek spasial dilakukan untuk mengetahui adanya efek spasial dependensi maupun spasial heterogenitas pada model. Efek spasial dependensi dapat diuji dengan menggunakan uji Moran's I dan Lagrange Multiplier, sedangkan untuk spasial heterogenitas dapat diuji dengan menggunakan uji Breusch-Pagan.

\subsubsection{Pengujian Indeks Moran}

Koefisien Moran's I atau indeks Moran digunakan untuk uji dependensi spasial atau autokorelasi antar amatan atau lokasi. Hipotesis yang digunakan adalah :

$\mathrm{H}_{0} \quad: \quad \mathrm{I}=0$ (tidak ada autokorelasi antar lokasi)

$\mathrm{H}_{1} \quad: \quad \mathrm{I} \neq 0$ (ada autokorelasi antar lokasi)

Nilai ekspektasi dari Moran's I ( Lee dan Wong, 2001 dalam Musfika, 2013) adalah :

$E(I)=I_{0}=-\frac{1}{n-1}$

dengan :

$x_{i} \quad: \quad$ data ke $\mathrm{i}(\mathrm{i}=1,2, \ldots, \mathrm{n})$

$x_{j} \quad: \quad$ data $\operatorname{ke~} \mathrm{j}(\mathrm{j}=1,2, \ldots, \mathrm{n})$

$\overline{\bar{x}} \quad$ : rata-rata data

$\operatorname{var}(\mathrm{I}): \quad$ varians Moran's I

E(I) : expected value Moran's I

Pengambilan keputusan adalah $\mathrm{H}_{0}$ ditolak jika $Z_{\text {hitung }}>Z_{\propto / 2}$. Jika $\mathrm{I}>\mathrm{I}_{0}$ maka data memiliki autokorelasi positif, hal ini berarti pola data mengelompok (cluster). Jika I $<\mathrm{I}_{0}$ maka data memiliki autokorelasi negatif yang berarti pola data menyebar. Uji statistik Moran's I,dibatasi nilai 1.0 (autokorelasi positif) dan -1.0 (autokorelasi negatif). 
Nilai autokorelasi spasial dikatakan kuat, apabila nilai tinggi dengan tinggi atau nilai rendah dengan rendah dari sebuah variabel berkelompok dengan daerah sekitarnya (common side).

Pola pengelompokan dan penyebaran antar lokasi dapat juga disajikan dengan Moran's scatterplot, yaitu sebuah diagram yang menunjukkan hubungan antara nilai amatan pada suatu lokasi (distandarisasi) dengan rata-rata nilai amatan dari lokasi-lokasi yang bertetanggaan dengan lokasi yang bersangkutan (Lee dan Wong, 2001 dalam Septiana dan Wulandari, 2009). Scatterplot diagram terbagi dalam 4 (empat) kuadran:

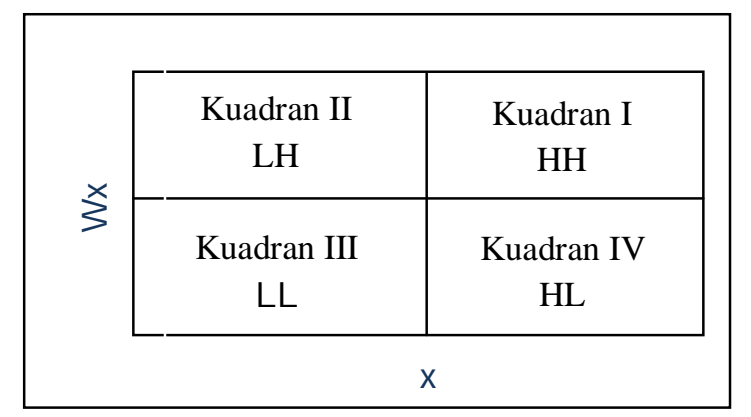

Gambar 4. Moran's Scatterplot

Lokasi-lokasi yang banyak berada di kuadran I dan III cenderung memiliki autokorelasi positif, sedangkan lokasi-lokasi yang banyak berada di kuadran II dan IV cenderung memiliki autokorelasi negatif (Anselin, 2003).

1. Kuadran I (High-High), menunjukkan lokasi yang mempunyai nilai amatan tinggi dikelilingi oleh lokasi yang mempunyai nilai amatan tinggi.

2. Kuadran II (Low-High), menunjukkan lokasi yang mempunyai nilai amatan rendah dikelilingi oleh lokasi yang mempunyai nilai amatan tinggi.

3. Kuadran III (Low-Low), menunjukkan lokasi yang mempunyai nilai amatan rendah dikelilingi oleh lokasi yang mempunyai nilai amatan rendah.

4. Kuadran IV (High-Low), menunjukkan lokasi yang mempunyai nilai amatan tinggi dikelilingi oleh lokasi yang mempunyai nilai amatan rendah.

\subsubsection{Pengujian Lagrange Multiplier (LM)}

Pada uji Lagrange Multiplier (LM), terdapat 3 (tiga) hipotesis yang dilakukan. Pertama, untuk SAR/Spatial Lag Model, $\mathrm{H}_{0}: \rho=0$ dan $\mathrm{H}_{1}: \rho \neq 0$. Kedua, untuk SEM, $\mathrm{H}_{0}: \lambda=0$ dan $\mathrm{H}_{1}: \lambda \neq 0$. Terakhir, untuk mixture model, $\mathrm{H}_{0}: \rho, \lambda=0$ dan $\mathrm{H}_{1}: \rho, \lambda \neq 0$. Dalam mengambil keputusan, terima $\mathrm{H}_{0}$ jika $\mathrm{LM} \leq \chi_{(\mathrm{q})}^{2}$ atau $\mathrm{p}$-value $>\alpha$ dan tolak $\mathrm{H}_{0}$ jika $\mathrm{LM}>\chi_{(\mathrm{q})}^{2}$ atau p-value $<\alpha$.

\subsubsection{Uji Breusch-Pagan (BP)}

Pada uji Breusch-Pagan (BP), hipotesis yang dilakukan, yaitu :

$\mathrm{H}_{0}: \sigma_{1}{ }^{2}=\sigma_{2}{ }^{2}=\ldots=\sigma_{\mathrm{n}}{ }^{2}=\sigma^{2}$ (tidak terdapat keragaman/heterogenitas antar lokasi) 
$\mathrm{H}_{1}$ : minimal ada satu $\sigma_{\mathrm{i}}^{2} \neq \sigma^{2}$ (terdapat keragaman/heterogenitas antar lokasi)

Dalam mengambil keputusan, terima $\mathrm{H}_{0}$ jika $\mathrm{BP} \leq \chi_{(\mathrm{p})}^{2}$ atau $\mathrm{p}$-value $>\alpha$ dan tolak $\mathrm{H}_{0} \mathrm{jika}$ $\mathrm{BP}>\chi_{(\mathrm{p})}^{2}$ atau $\mathrm{p}$-value $<\alpha$.

\section{TEMUAN DAN PEMBAHASAN}

\subsection{Hasil Analisis Regresi yang Signifikan Mempengaruhi Jumlah Pasar Modern di Kota Yogyakarta, Kabupaten Sleman dan Bantul}

Model dalam penelitian ini menggunakan atribut demografi dan sosioekonomi wilayah yang bersangkutan. Dari hasil studi literatur dan observasi di lapangan, diperoleh 8 (delapan) variabel independenyang dimodelkan dalam model regresi klasik sebagai berikut :

$$
\begin{aligned}
\operatorname{Ln}\left(\operatorname{JmlToko}_{i}\right)= & \beta_{0}+\beta_{1} \operatorname{Ln}\left(\text { Density }_{\mathrm{i}}\right)+\beta_{2} \operatorname{Ln}\left(\operatorname{LRoad}_{\mathrm{i}}\right)+\beta_{3} \operatorname{Ln}\left(\text { SH15atas }_{\mathrm{i}}\right)+ \\
& \beta_{4} \operatorname{Ln}\left(\text { SHSMA }_{\mathrm{i}}\right)+\beta_{5} \operatorname{Ln}\left(\text { SHKKMisk }_{\mathrm{i}}\right)+\beta_{6} \operatorname{Ln}\left(\text { TRAD }_{\mathrm{i}}\right)+ \\
& \beta_{7} \operatorname{JOGBorder}_{\mathrm{i}}+\beta_{8} \text { SLMBorder }_{\mathrm{i}}+\beta_{9} \text { BTLBorder }_{\mathrm{i}}+\varepsilon_{\mathrm{i}} \ldots \ldots \ldots \ldots
\end{aligned}
$$

Transformasi logaritma yang digunakan dalam penelitian ini dipilih dengan mempertimbangkan asumsi-asumsi pada model regresi linear klasik, yaitu normalitas, multikolinearitas dan heteroskedastisitas. Perbandingan hasil uji asumsi model regresi klasik pada model log-linear dengan model linear disajikan pada Tabel 2 dan Tabel 3.

Tabel 2. Perbandingan Hasil Uji Normalitas dan Heteroskedastisitas

\begin{tabular}{lcccc}
\hline \multirow{2}{*}{$\begin{array}{c}\text { Uji Asumsi Model Regresi } \\
\text { Linear Klasik }\end{array}$} & \multicolumn{2}{c}{ Model Log-Linear } & \multicolumn{2}{c}{ Model Linear } \\
\cline { 2 - 5 } & Value & Prob & Value & Prob \\
\hline Jarque-Bera (Uji Normalitas) & 4.025031 & 0.1336520 & 18.95611 & 0.0000765 \\
Breusch-Pagan (Uji Heteroskedastisitas) & 8.210201 & 0.5131099 & 66.34741 & 0.0000000 \\
\hline
\end{tabular}

Tabel 3. Perbandingan Hasil Uji Multikolinearitas

\begin{tabular}{cllll}
\hline \multirow{2}{*}{$\begin{array}{c}\text { Uji Asumsi Model Regresi } \\
\text { Linear Klasik }\end{array}$} & \multicolumn{2}{c}{ Variable } & Value & \multicolumn{2}{c}{ Mariable } & Value \\
\cline { 2 - 5 } Variance Inflation Factor & Ln(Density & 3.958 & Density & 3.721 \\
(Uji Multikolinearitas) & Ln(LRoad) & 2.840 & LRoad & 2.862 \\
& Ln(SH15atas) & 3.451 & SH15atas & 2.987 \\
& Ln(SHSMA) & 5.199 & SHSMA & 5.600 \\
& Ln(SHKKMisk) & 1.492 & SHKKMiskin & 1.420 \\
& Ln(TRAD) & 1.343 & JmlPsrTrad & 1.433 \\
& JOGBorder & 1.865 & JOGBorder & 1.919 \\
& SLMBorder & 1.266 & SLMBorder & 1.205 \\
& BTLBorder & 1.404 & BTLBorder & 1.348 \\
\hline
\end{tabular}

Pada model log-linear, hasil uji Jarque-Bera menunjukkan probabilitas yang tidak signifikan, dengan demikian hipotesis tentang residual yang terdistribusi normal 
dapat diterima. Hasil uji Breusch-Pagan juga menunjukkan probabilitas yang tidak signifikan sehingga hipotesis tentang homoskedastisitas dapat diterima, atau dengan kata lain, tidak terdapat permasalahan heteroskedastisitas. Nilai VIF (Variance Inflation Factor) pada variabel-variabel independen tidak menunjukkan adanya masalah multikolinearitas karena nilai VIF semuanya lebih kecil daripada 10. Sedangkan pada model linear, hasil uji Jarque-Bera dan Breusch-Pagan menunjukkan probabilitas yang signifikan, dengan demikian hipotesis tentang distribusi normal dan homoskedastisitas ditolak, atau residualnya tidak terdistribusi normal dan terdapat permasalahan heteroskedastisitas.

Faktor-faktor yang signifikan mempengaruhi jumlah pasar modern didapatkan dari hasil regresi klasik dengan menggunakan estimasi parameter Ordinary Least Square (OLS) yang disajikan pada Tabel 4 berikut :

Tabel 4. Hasil Estimasi OLS

\begin{tabular}{lccc}
\hline \multicolumn{1}{c}{ Variable } & Coefficient & Std. Error & Probability \\
\hline Constant & -6.364238 & 3.126864 & 0.0488342 \\
LnDensity & 0.5210453 & 0.1989075 & $\mathbf{0 . 0 1 2 5 8 2 7} *$ \\
LnLRoad & 0.6748598 & 0.27901 & $\mathbf{0 . 0 2 0 4 7 1 1 *}$ \\
LnSH15atas & 2.271947 & 3.360392 & 0.5030741 \\
LnSHSMA & -0.4306961 & 1.315997 & 0.7452542 \\
LnSHKKMisk & -1.827975 & 1.893754 & 0.3405152 \\
LnTRAD & 0.4102086 & 0.276621 & 0.1463411 \\
JOGBorder & 1.148449 & 0.4910195 & $\mathbf{0 . 0 2 4 6 9 9 9 *}$ \\
SLMBorder & 0.1352834 & 0.3168342 & 0.6718004 \\
BTLBorder & 0.3924665 & 0.2719876 & 0.1572257 \\
\hline R ${ }^{2}$ & 0.610742 & & \\
Log Likelihood & -44.5879 & & \\
AIC & 109.176 & & 0.1336520 \\
Jarque-Bera & 4.025031 & & 0.5131099 \\
Breusch-Pagan & 8.210201 & & 0.0347045 \\
Lagrange Multiplier (error) & 4.4596550 & & \\
\hline * signifikan pada $\alpha=5 \%$ & & &
\end{tabular}

Berdasarkan hasil regresi klasik, jumlah gerai/toko/pasar modern akan meningkat seiring dengan semakin meningkatnya tingkat kepadatan dan panjang jalan yang diaspal. Jumlah gerai/toko/pasar modern juga diprediksi meningkat jika lokasi berdekatan dengan batas kotaYogyakarta. Hal ini dapat dipahami, mengingat kota Yogyakarta merupakan pusat administrasi pemerintahan Daerah Istimewa Yogyakarta. Disamping itu, predikat kota pendidikan dan pariwisata menjadikan arus urbanisasi di kota Yogyakarta tergolong tinggi. Untuk beberapa wilayah di kabupaten Sleman, jumlah pasar modern tergolong besar, terutama di wilayah dengan kegiatan perekonomian yang tinggi. 
Kemudahan akses transportasi yang ditunjang oleh sarana infrastruktur jalan yang baik menjadi salah satu pertimbangan bagi pengembang pasar modern untuk menentukan lokasi pasar modern. Fasilitas umum seperti lembaga pendidikan, kesehatan (rumah sakit, klinik, puskesmas) serta pasar umumnya berada di lokasi yang mudah dijangkau dengan moda transportasi. Fakta yang ada membuktikan bahwa pasar modern berlokasi di lokasi padat penduduk dan ditunjang oleh akses transportasi yang baik pula.

Beberapa variabel yang tidak signifikan mempengaruhi jumlah pasar modern adalah rasio penduduk berusia 15 tahun keatas, rasio penduduk berpendidikan minimal SMA, rasio kepala keluarga/rumah tangga miskin dan jumlah pasar tradisional serta perbatasan dengan kabupaten Sleman dan Bantul. Rasiorumah tangga miskin yang diperoleh dari perhitungan jumlah rumah tangga miskin dibagi dengan total rumah tangga merupakan faktor yang tidak turut mempengaruhi jumlah pasar modern, hal ini dapat terjadi karena penduduk yang tinggal di Yogyakarta banyak diantaranya merupakan kaum pendatang yang didominasi oleh kelompok pelajar dan mahasiswa serta wisatawan.

Hasil regresi klasik juga menemukan bahwa faktor pendidikan tidak mempengaruhi jumlah pasar modern. Keterbukaan kota Yogyakarta yang menjadi salah satu sentrum penting pendidikan dan pariwisata di Indonesia telah menjadikan Yogyakarta sebagai arena pertemuan sosial dan kultural dari berbagai etnis di Indonesia. Bercampurnya kultur budaya mengakibatkan perubahan pola gaya hidup masyarakat, termasuk perubahan gaya hidup berbelanja tanpa memandang tingkat pendidikan yang dimiliki.

Perbatasan dengan kabupaten Sleman dan Bantul tidak secara signifikan berpengaruh pada jumlah pasar modern. Kecamatan yang tidak berbatasan langsung dengan kota Yogyakarta tetapi berbatasan dengan kecamatan yang masuk wilayah kabupaten Sleman atau Bantul memiliki pasar modern yang relatif sedikit dibandingkan dengan kecamatan yang berbatasan langsung dengan kota Yogyakarta. Jumlah pasar modern di wilayah yang berbatasan langsung dengan kota Yogyakarta mempunyai kecenderungan yang tinggi. Sedangkan untuk wilayah yang tidak berbatasan langsung dengan kota Yogyakarta namun berbatasan langsung dengan kabupaten Sleman dan/atau Bantul memiliki pola beragam karena karakteristik daerah yang berbeda.Tren menunjukkan bahwa pembangunan pasar modern mengarah ke selatan atau perbatasan dengan kabupaten Bantul. Hal ini dapat disebabkan karena faktor kebijakan pemerintah kabupaten Bantul yang melarang pendirian toko modern berstatus waralaba. Baru pada tahun 2010, pemerintah kabupaten Bantul mengeluarkan peraturan yang berkaitan dengan penataan toko modern yaitu melalui peraturan Bupati Bantul nomor 12 tahun 2010. Celah inilah yang bisa jadi dimanfaatkan oleh pengembang untuk membangun bisnis di lokasi yang berbatasan dengan kabupaten Bantul. 


\subsection{Hasil Analisis Efek Spasial}

Model yang dihasilkan melalui regresi klasik diatas belum mempertimbangkan adanya spatial dependence atau spasial autokorelasi. Berikut ini adalah hasil pengujian efek spasial pada model regresi klasik dan pembuatan model spasial untuk memilih model terbaik.

\subsubsection{Hasil Pembentukan Matriks Pembobot Spasial (W)}

Hubungan kedekatan (neighbouring) antar lokasi dinyatakan dalam matrik pembobot spasial Wsebagai penanda adanya keterkaitan suatu wilayah dengan wilayah lain dan merupakan ciri pemodelan spasial.Matriks $W$ merupakan representasi tetangga bagi setiap wilayah. Tetangga adalah unit analisis lain yang berbatasan langsung atau memiliki keterkaitan/hubungan atas dasar kriteria/skenario tertentu. Skenario spatial weight matrix yang dipilih dalam penelitian ini adalah queen contiguity mengingat unit observasinya berupa data area (Polygon atau Lattice Data) yang menunjukkan lokasi berupa luasan, seperti negara, kabupaten, kota, kecamatan dan sebagainya.

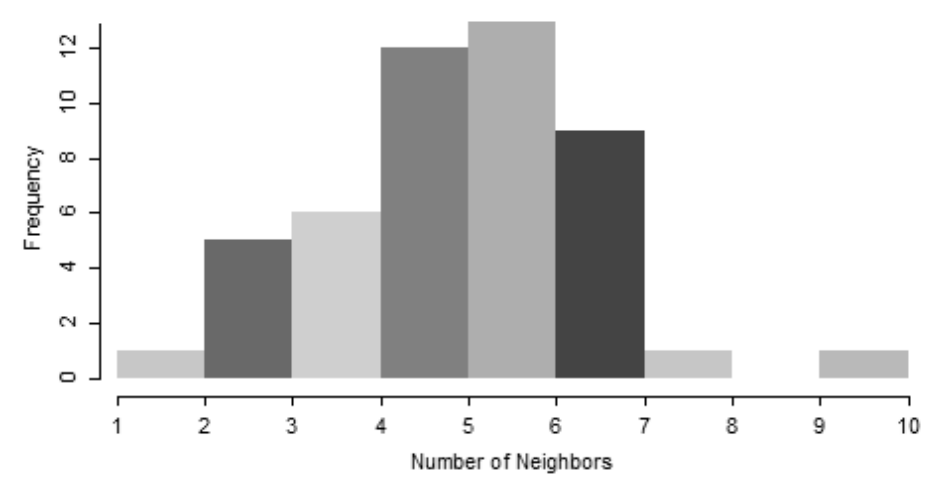

Gambar 4. Connectivity Histogram

Pada gambar 4. tampak bahwa pola konektivitas yang terjadi adalah semakin dekat dengan pusat wilayah penelitian, jumlah tetangga yang dimiliki akan semakin banyak, dan sebaliknya semakin mendekati bagian terluar pada wilayah penelitian, jumlah tetangga yang dimiliki akan semakin sedikit.

\subsubsection{Hasil Pengujian Efek Spasial}

Pengujian efek spasial dilakukan untuk melihat apakah data setiap variabel memiliki pengaruh spasial pada lokasi. Pengujian spasial dependence menggunakan statistik Moran's I. Nilai ekspektasi dari Moran's I adalah :

$$
E E(I)=I I_{0}=-\frac{1}{(n n-1)}
$$

dimana, $\mathrm{n}=$ banyaknya observasi 
Jika I > Io, maka nilai autokorelasi bernilai positif, hal ini berarti bahwa pola data membentuk kelompok (cluster), I = Io artinya tidak terdapat autokorelasi spasial, dan I < Io artinya nilai autokorelasi bernilai negatif, hal ini berarti pola data menyebar. Dengan menggunakan formula diatas, diperoleh nilai ekpektasi Moran's I :

$$
E E(I I)=I I_{0}=-\frac{1}{(48-1)}=-0.021277
$$

Sedangkan dari hasil analisis nilai Moran's I dengan menggunakan perangkat lunak Geoda, diperoleh nilai $\mathrm{I}=0.151196$. Berdasarkan hasil perhitungan $\mathrm{E}(\mathrm{I})$ dan nilai $\mathrm{I}$ terlihat bahwa nilai Moran's I > $\mathrm{I}_{0}$, hal ini menunjukkan adanya tingkat ketergantungan spasial berupa autokorelasi spasial positif. Meskipun Moran's I value jauh dari nilai +1 , tetapi pola tersebut berpotensi pada pola mengelompok (clustered) secara spasial.

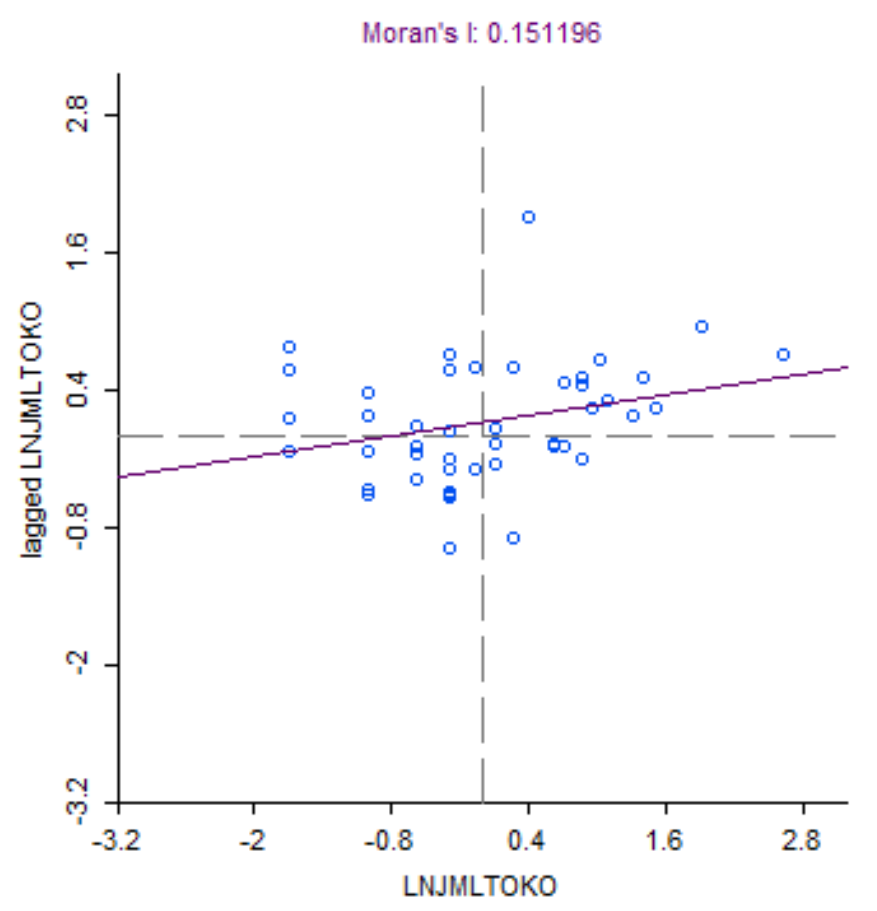

Gambar 5. Diagram Moran's I scatterplot

Moran's I scatterplot digunakan untuk analisis Global Spatial Autocorrelation yang menunjukkan hubungan antara nilai amatan pada suatu lokasi dengan rata-rata nilai amatan dari lokasi-lokasi yang bertetanggaan dengan lokasi yang bersangkutan (Anselin, 2003). Gambar 5 menunjukkan pola mengelompok pada kuadran I dan III, sehingga memiliki spasial autokorelasi positif. Hal ini mengindikasikan bahwa kecamatan dengan banyak gerai/toko/pasar modern mengelompok dengan kecamatan yang juga memiliki banyak gerai/toko/pasar modern. Kecamatan dengan sedikit gerai/toko/pasar modern mengelompok dengan kecamatan yang juga memiliki sedikit gerai/toko/pasar modern. 


\subsubsection{Menentukan Model Terbaik}

Tabel 5. Hasil Regresi Spatial Lag dan Spatial Error

\begin{tabular}{lcc}
\hline \multicolumn{1}{c}{ Model } & AIC & LL \\
\hline Spatial Lag & 109.84 & -43.92 \\
Spatial Error & 98.2493 & -39.124669 \\
\hline
\end{tabular}

Model yang terbaik yang bisa dipilih adalah yang mempunyai nilai AIC kecil dan nilai LL besar, sehingga dari tabel 5. dapat disimpulkan bahwa model terbaik yang dipilih adalah spatial error model (SEM)yang dapat menjelaskan model jumlah pasar modern di kota Yogyakarta, kabupaten Sleman dan Bantul.

Untuk menentukan model terbaik, selain dengan cara membandingkan nilai LL dan AIC pada model spatial lag dan spatial error, menurut Anselin (2005) dalam Higazi (2011) dapat dilakukan dengan membandingkan nilai Wald test (W) dan Likelihood Ratio (LR) value pada hasil estimasi SEM (tabel 6) serta Lagrange Multiplier (LM) value pada hasil estimasi OLS (tabel 5). Model terbaik akan memenuhi ketentuan : W $\geq \mathrm{LR} \geq \mathrm{LM}$. Dari hasil estimasi SEM diperoleh nilai $\mathrm{W}=(-4.896613)^{2}=23.97682$, LR $=10.92646$ dan $\mathrm{LM}=4.4596550$, sehingga ketentuan bahwa $\mathrm{W} \geq \mathrm{LR} \geq \mathrm{LM}$ terpenuhi.

Tabel 6. Hasil Estimasi SEM

\begin{tabular}{lccc}
\hline \multicolumn{1}{c}{ Variable } & Coefficient & Std. Error & Probability \\
\hline Constant & -2.75549 & 2.119364 & 0.1935498 \\
LnDensity & 0.317051 & 0.1268377 & $\mathbf{0 . 0 1 2 4 3 1 3} *$ \\
LnLRoad & 0.5512717 & 0.1800114 & $\mathbf{0 . 0 0 2 1 9 5 6 *}$ \\
LnSH15atas & -1.088028 & 2.099362 & 0.6042726 \\
LnSHSMA & 1.044753 & 0.8547583 & 0.2216025 \\
LnSHKKMisk & -1.680521 & 1.271056 & 0.1861200 \\
LnTRAD & 0.2653555 & 0.198422 & 0.1811153 \\
JOGBorder & 1.805326 & 0.3740683 & $\mathbf{0 . 0 0 0 0 0 1 4} *$ \\
SLMBorder & 0.1031821 & 0.2053338 & 0.6153093 \\
BTLBorder & 0.5288912 & 0.1636851 & $\mathbf{0 . 0 0 1 2 3 3 1 *}$ \\
$\boldsymbol{\lambda}$ & -0.9026745 & 0.1843467 & 0.0000010 \\
\hline R & 0.741247 & & \\
Likelihood Ratio Test & 10.92646 & & 0.0009480 \\
\hline
\end{tabular}

* signifikan pada $\alpha=5 \%$

Dari hasil output diatas, model SEM yang dapat dibentuk adalah sebagai berikut :

$$
\begin{aligned}
& \operatorname{Ln}\left(\operatorname{JmlToko}_{i}\right)=-2.756-0.903 \sum_{j=1, i \neq j}^{n} W_{i j} u_{j}+0.317 \operatorname{Ln}\left(\text { Density }_{i}\right)^{*}+0.551 \operatorname{Ln}\left(\operatorname{LRoad}_{i}\right)^{*} \\
& -1.088 \operatorname{Ln}\left(\text { SH15atas }_{i}\right)+1.045 \operatorname{Ln}\left(\text { SHSMA }_{i}\right)-1.681 \operatorname{Ln}\left(\text { SHKKMisk }_{i}\right) \\
& +0.265 \operatorname{Ln}\left(\text { TRAD }_{i}\right)+\mathbf{1 . 8 0 5}\left(\text { JOGBorder }_{i}\right)^{*}+0.103\left(\text { SLMBorder }_{i}\right) \\
& +0.529\left(\text { BTLBorder }_{i}\right)^{*}+\varepsilon_{i}
\end{aligned}
$$


Setelah mengontrol keberadaan spasial dependensi, terdapat 1 (satu) variabel yang tidak signifikan pada model klasik menunjukkan signifikansi pada model spasial. Pada model klasik, faktor-faktor yang mempengaruhi jumlah pasar modern adalah kepadatan penduduk, panjang jalan yang diaspal dan perbatasan dengan kota Yogyakarta. Sedangkan untuk model spasial, faktor perbatasan dengan kabupaten Bantul juga menjadi faktor yang signifikan mempengaruhi jumlah pasar modern.

Model regresi klasik maupun model spasial error menghasilkan 3 (tiga) peubah nyata yang sama dan tanda koefisien yang konsisten. Model spasial error mengindikasikan bahwa terdapat beberapa independent variable yang tidak masuk dalam model namun sesungguhnya secara kolektif mempengaruhi variabel terikat (dependent variable). Harga tanah serta kebijakan pemerintah daerah yang berkaitan dengan penataan pasar modern diduga menjadi faktor yang tidak terobservasi sehingga tidak masuk dalam model dan muncul sebagai variabel gangguan (error term). Sedangkan koefisien $\lambda$ yang nyata menunjukkan bahwa jika suatu wilayah yang dikelilingi oleh wilayah lain sebanyak $n$, maka pengaruh dari masing-masing wilayah yang mengelilinginya dapat diukur sebesar -0.903 dikali rata-rata error disekitarnya.

Koefisien peubah kepadatan penduduk sebesar 0.317 menunjukkan bahwa setiap kenaikan tingkat kepadatan penduduk sebesar 1\% akan menambah jumlah pasar modern sebesar $0.317 \%$ dan error spasial berkorelasi antar daerah, dengan asumsi faktor lain dianggap konstan. Demikian pula dengan variabel panjang jalan yang diaspal, jika faktor tersebut mengalami kenaikan $1 \%$ maka akan menambah jumlah pasar modern sebesar $0.551 \%$. Jumlah pasar modern juga akan meningkat terutama di wilayah yang berbatasan dengan kota Yogyakarta dan kabupaten Bantul. Keempat variabel tersebut mempunyai hubungan yang positif dengan jumlah pasar modern.

\subsection{Perbandingan Model Klasik dan Spatial Error Model}

Dari tabel 7, tampak bahwa model spatial error memiliki hasil statistik yang lebih baik dibanding model klasik, baik dari nilai $\mathrm{R}^{2}$, AIC maupun LL. Variabel-variabel demografi dan sosioekonomi yang digunakan dalam model spasial memberikan kontribusi sebesar 74\% ke dalam model, atau dengan kata lain, 74\% variasi dalam model dapat dijelaskan oleh regresi spasial tersebut.

Tabel 7. Statistik Model Klasik dan Model SEM

\begin{tabular}{lcc}
\hline & Model Klasik & Model SEM \\
\hline $\mathrm{R}^{2}$ & 0.610742 & 0.741247 \\
Log Likelihood & -44.5879 & -39.124669 \\
AIC & 109.176 & 98.2493 \\
\hline
\end{tabular}




\section{KESIMPULAN}

Hasil penelitian ini menunjukkan adanya dependensi spasial dalam hal lokasi pasar modern. Artinya bahwa keberadaan pasar modern di suatu wilayah dipengaruhi oleh keberadaan pasar modern di wilayah tetangganya. Hal ini didasarkan pada hasil uji nilai Moran's I dimanaterdapat hubungan autokorelasi spasial positif. Meski nilainya agak lemah karena Moran's I value yang dihasilkan jauh dari nilai +1 , namun pola tersebut berpotensi pada pola mengelompok (clustered) terutama di kota Yogyakarta dan wilayah yang berbatasan dengan kota Yogyakarta seperti kecamatan Depok di kabupaten Sleman, kecamatan Banguntapan, Kasihan dan Sewon di kabupaten Bantul. Pola ini sejalan dengan pola sebaran pasar modern yang divisualisasikan dengan Geographical Information System (GIS).

Perhitungan yang ada menunjukkan bahwadepensi spasial dapat dijelaskan olehspatialerror model yang digunakan sebagai model terbaik untuk menjelaskan faktorfaktor yang mempengaruhi jumlah pasar modern di kota Yogyakarta, kabupaten Sleman dan Bantul.Faktor-faktor yang terbukti signifikan mempengaruhi jumlah pasar modern ialah kepadatan penduduk, kualitas infrastruktur jalan (panjang jalan yang diaspal) dandummy perbatasan wilayah dengan kota Yogyakarta dan Kabupaten Bantul. Artinya bahwa selain di pusat kota, pasar modern banyak terdapat di kecamatan yang berbatasan dengan Yogyakarta dan Kabupaten Bantul. Harga tanah serta kebijakan pemerintah daerah yang berkaitan dengan penataan pasar modern diduga menjadi faktor yang tidak terobservasi sehingga tidak masuk dalam model dan muncul sebagai variabel gangguan (error term).

\section{DAFTAR PUSTAKA}

Anselin, L. (1988). Spatial Econometrics: Methods and Models. Kluwer Academic Publisher.

Anselin, L. (2003). GeoDa 0.9 User's Guide. Center for Spatially Integrated Social Science.

Anselin, L. (2005). Exploring Spatial Data with GeoDa ${ }^{T M}$. A Workbook: University of Illinois.

Hadiarta, A. P. (2013). Spatial Hedonic Price Model untuk Penilaian Harga Tanah, Studi Kasus. Kota Depok. Tesis PPIE UI.

Henderson, V., Kuncoro, A. \& Matt, T. (1995). Industrial Development in Cities. Journal of Political Economy, 103(5), 1067-1090.

Higazi, S. F., Abdel-Hady, D. H., \& Al-Oulfi, S. A. (2013). Application of Spatial Regression Models to Income Poverty Ratios in Middle Delta Contiguous 
Counties in Egypt. Pakistan Journal of Statistics and Operation Research, 9(1), 93-110.

Indonesian Commercial Newsletter. (2011). Perkembangan Bisnis Ritel Modern. Retrieved from http://www.datacon.co.id.

Komisi Pengawas Persaingan Usaha. (2012). Negeri Surga Ritel. Retrieved from http://www.kppu.go.id/id/wp-content/uploads/2013/01/Kompetisi-34.pdf.

LeSage, J. \& Pace, R. K. (2009). Introduction to Spatial Econometrics. New York: CRC Press.

O’Sullivan, A. (2003). Urban Economics. McGraw-Hill/Irwin.

Ozuduru, B. H. \& Jean-Michel, G. (2009). Modelling the Spatial Dependency of Shopping Market Potential Using Published Data: A Trade Area Analysis Example. Papers, World Conference of Spatial Econometrics, Faculty of Economics and Business, University of Barcelona.

Ozuduru, B. H. \&Cigdem, V. (2011). Spatial Statistics Methods in Retail Location Research: A Case Study of Ankara, Turkey. Procedia Environmental Sciences, 7, 287-292. Published by Elsevier Ltd.

Ozuduru, B. H. (2013). Assessment of Spatial Dependence Using Spatial Autoregression Models: Empirical Analysis of Shopping Center Space Supply in Ohio. Journal of Urban Planning and Development, 139(1), 12-21.

Pandin, M. L. (2009). Potret Bisnis Ritel di Indonesia : Pasar Modern. Economic Review No. 215, Maret 2009. Retrieved from http://www.academia.edu/ 1069998/Potret_Bisnis_Ritel_Di_Indonesia_Pasar_Modern.

Panjaitan, W. M. (2012).Penerapan Regresi Spasial pada Pemodelan Kasus Ketergantungan Spasial (Studi Kasus: Indeks Pembangunan Manusia di Indonesia Tahun 2010). IPB.

Rati, M. (2013). Model Regresi Spasial untuk Anak Tidak Bersekolah Usia Kurang 15 Tahun di Kota Medan. Skripsi, USU, Medan.

Septiana, L. \& Wulandari, S. P. (2009). Pemodelan Remaja Putus Sekolah Usia SMA di Provinsi Jawa Timur dengan Menggunakan Metode Regresi Spasial. Retrieved from http://www.digilib.its.ac.id/public/ITS-Undergraduate-16199-Cover_idpdf.pdf. 